\title{
HUKUM JUAL BELI ANGSURAN (KREDIT) MENURUT SYARIAH
}

\author{
H. Al Hafid Ibnu Qayyim, M.Th.I. \\ Universitas Widya Gama Mahakam Samarinda \\ kayyink@gmail.com \\ Drs. H. Rujiansyah, M.H. \\ Universitas Widya Gama Mahakam Samarinda \\ rujiruji1955@gmail.com
}

\begin{abstract}
Abstrak
Tujuan dari penelitian ini adalah untuk mengetahui secara langsung bagaimana prosedur jual beli angsuran (kredit) dan bagaimana hukumnya menurut syariah.

Dalam rangka mendorong pengembangan ekonomi Islam, keuangan dan perbankan syariah secara nasional, diperlukan upaya meneliti dan memperluas keilmuan terkait jual beli angsuran (kredit) yang sesuai dengan syariah, demi kenyamanan dan keamanan masyarakat luas, khususnya umat Islam dalam jual beli sistem angsuran (kredit), sehingga umat Islam tidak ragu dan takut terjerumus pada riba dan kepastian hukum jual beli angsuran (kredit) dalam syariah Islam.

Hasil dari penelitian ini ternyata jual beli angsuran (kredit) itu boleh menurut syariah selama tidak ada kezaliman di dalamnya, tidak ada unsur riba, serta dilakukan atas dasar sukarela.
\end{abstract}

Kata Kunci: Jual Beli, Angsuran, Kredit, Riba.

\section{PENDAHULUAN}

\section{A. Latar Belakang}

Islam tidak hanya mengajarkan bagaimana ritual ibadah semata, tetapi Islam juga mengajarkan bagaimana tatacara bermuamalah dengan sesama termasuk di dalamnya jual beli secara angsuran atau kredit. Oleh karena itu, tentu umat Islam memiliki kewajiban dalam memahami aturan-aturan hukum yang bersumber dari wahyu, al-Qur'an dan al-Sunnah.

Gambaran jual beli angsuran (kredit) adalah menjual belikan dengan sistem pembayaran yang tertunda yaitu dengan cara mencicil dalam jumlah tertentu dan dalam jangka waktu tertentu yang telah disepakati. 
Di zaman milenial ini perkembangan ekonomi bertambah pesat. Beragam cara ditawarkan oleh para pebisnis untuk bersaing mengambil hati para pelanggan dan pembeli. Niagawan muslim yang orientasinya tidak hanya pada keuntungan dunia, sudah semestinya cerdik dan cerdas menganalisa fenomena yang ada, agar mengetahui bagaimana pandangan syariah terhadap transaksi seperti ini. Dengan demikian tidak mudah terjerumus ke dalam satu perkara larangan-Nya.

Perkembangan perikatan akad dalam dunia bisnis sangat pesat, seiring dengan perkembangan ilmu pengetahuan dan teknologi. Ketika ada persoalan baru, fikih dituntut untuk menjawab persoalan tersebut dalam kacamata syariat.

Penelitian ini sangat penting dilakukan mengingat hampir semua sistem dalam jual beli, terutama dalam jual beli angsuran (kredit) lebih banyak merugikan pembeli, oleh karena itu dalam penelitian kali ini fokus pembahasannya adalah tentang hukum jual beli angsuran atau kredit menurut syariah Islam.

\section{B. Rumusan Masalah}

Dari latar belakang di atas rumusan masalah dari penelitian ini, sebagai berikut:

1. Bagaimana prosedur jual beli dengan sistem angsuran (kredit)?

2. Bagaimana hukum jual beli dengan sistem angsuran (kredit) dalam Islam?

\section{Tujuan Penelitian}

Berdasarkan rumusan masalah di atas maka tujuan dilakukannya penelitian ini adalah:

1. Untuk mengetahui prosedur jual beli dengan sistem angsuran (kredit).

2. Untuk mengetahui hukum jual beli angsuran (kredit) dalam Islam.

\section{Manfaat Penelitian}

Manfaat dilakukannya penelitian ini diharapkan antara lain:

1. Sebagai masukan dan saran untuk menambah wawasan bagi masyarakat di era milenial yang semakin berkembang ini terkhusus dalam hal jual beli dengan system angsuran (kredit).

2. Sebagai referensi penelitian pengembangan lebih lanjut dalam mendapatkan suatu hukum Islam tentang jual beli angsuran (kredit).

\section{METODE PENELITIAN}

\section{A. Metode}

Untuk menganalisa obyek penelitian tersebut, maka peneliti akan menggunakan metode dokumentasi (pengumpulan data) dengan berusaha memaparkan atau menyajikan data dan informasi secara mendalam dan utuh kemudian dianalisis.. 


\section{B. Jenis Penelitian}

Penelitian ini menggunakan jenis penelitian kepustakaan (Library Research) dan kualitatif sebagai penelitian yang tidak mengadakan perhitungan. ${ }^{1}$ Analisis data akan digunakan dalam usaha mencari dan mengumpulkan data, menyusun, menggunakan serta menafsirkan data yang sudah ada. Berdasarkan hal itu, maka peneliti hendak menguraikan secara lengkap, teratur dan teliti terhadap suatu obyek penelitian, yaitu menguraikan dan menjelaskan hukum mengenai jual beli angsuran (kredit) menurut syariah

\section{Pendekatan Penelitian}

Sesuai dengan judulnya yakni hukum jual beli angsuran (kredit), maka pendekatan yang digunakan dalam penelitian ini ialah pendekatan berbasis penelitian sumber ajaran Islam dengan pendekatan kajian ilmu hadis dan ushul fiqh sebagai alat analisis dalam penelitian ini.

\section{Sumber Data}

Data primer adalah sumber ajaran Islam berupa wahyu yakni alQur'an dan al-Hadits. Data sekunder yaitu sejumlah referensi yang relevan dengan penelitian ini terutama kitab-kitab atau buku-buku yang terkait dengan jual beli dalam Islam.

\section{F. Pengumpulan Data}

Data dikumpulkan dari sumber primer yaitu al-Qur'an dan al-Hadits yang terkait dengan pokok bahasan di samping sumber sekunder dari kitabkitab maupun buku-buku karya tulis para ulama yang terkait dengan jual beli dalam Islam.

\section{G. Teknik Pengolahan Data dan Teknik Analisis Data}

Penelitian ini menggunakan data kepustakaan. Data tersebut digunakan untuk menelusuri hukum jual beli angsuran (kredit) dalam syariah. Peneliti akan mendeskripsikan dan menganilisis untuk menemukan aturan hokum sebenarnya terkait jual beli angsuran dalam Islam itu. Langkah-langkah pengolahan datanya dengan mendeskripsikan pengertian dan sistem angsuran (kredit) lalu menganalisis data-data primer dan sekunder untuk menghasilkan sebuah kesimpulan hukum syariah dari datadata tersebut.

\section{HASIL DAN PEMBAHASAN}

\section{A. Oardh Dalam Ajaran Islam}

\section{Pengertian Qardh}

Qardh ditinjau dari sudut bahasa, menurut Mahmud Yunus berarti alqath ' $u$ yakni menggunting atau memotong. ${ }^{2}$ Disebut demikian sebab apa yang

1Lexy J. Moleong, Metodelogi Penelitian Kualitatif (Bandung: PT. Remaja Rosdakarya, 2010), h. 2. 
diberikan kepada orang yang meminjam harta merupakan bagian potongan dari harta orang yang memberikan pinjaman tersebut. ${ }^{3}$

Bila ditinjau dari sudut istilah, maka qardh adalah memberikan harta kepada seseorang yang membutuhkan dan bisa diminta kembali dengan jumlah yang sama, atau meminjamkan uang tanpa mengharapkan imbalan sepeserpun. ${ }^{4}$ Dapat pula difahami dengan transaksi pinjam meminjam murni tanpa ada tambahan sedikitpun tanpa bunga yang dikembalikan hanya uang pokok pada waktu tertentu. ${ }^{5}$ Karenanya qardh itu merupakan akad yang saling membantu (ta'awun) dan bukan sebuah akad yang bersifat komersial. ${ }^{6}$

Atang Abd Hakim mengutip suatu fatwa bahwa qardh adalah akad pinjaman kepada nasabah dengan ketentuan bahwa nasabah wajib memulangkan dana yang diambilnya kepada Lembaga Keuangan Syariah (LKS) pada waktu yang telah disepakati bersama oleh LKS dan nasabah. ${ }^{7}$

Pada hakikatnya qardh sebenarnya merupakan pertolongan (bantuan) dan kasih sayang bagi yang meminjam, bukan sebagai sarana untuk mencari keuntungan bagi yang meminjamkan karena di dalamnya tidak ada imbalan atau kelebihan pengembalian sedikitpun. Di dalamnya mengandung nilai kemanusiaan dan sosial untuk memenuhi kebutuhan dari peminjam. Pengambilan keuntungan oleh yang meminjamkan (muqtaridh) harta membatalkan kontrak qardh. Sesuai dengan kaidah yang mengatakan bahwa setiap peminjaman yang mengandung unsur pengambilan keuntungan yang dilakukan oleh yang meminjamkan adalah haram.

Dapat ditarik sebuah kesimpulan dari beberapa penjelasan di kalangan ulama mazhab fiqh bahwa qardh merupakan perjanjian atau kesepakatan antara pihak peminjam dan yang meminjamkan hartanya yang dapat diminta atau ditagih kembali harta tersebut tanpa mengharapkan imbalan apa-apa sedikit pun.

Qardh diatur dalam ketentuan fatwa DSN MUI No.19/DSN-MUI/IV/2001 yang menyatakan bahwa:

\section{Pertama: Ketentuan Umum Al-Qardh}

1. Qardh adalah pinjaman yang diberikan kepada nasabah yang memerlukan.

2. Nasabah qardh wajib mengembalikan jumlah pokok yang diterima pada waktu yang telah disepakati bersama.

3. Biaya administrasi dibebankan kepada nasabah. LKS dapat meminta jaminan kepada nasabah bilamana dipandang perlu.

3Ahmad Wardi Mulich, Fiqh Muamalat (Jakarta: AMZAH, 2010), h. 273-274.

4Muhammad Syafi'i Antonio, Bank Syari'ah Dari Teori Ke Praktik (Jakarta: Gema Insani, 2001), h. 131.

5Ascaya, Akad dan Produk Bank Syari'ah (Jakarta: PT. Raja Grafindo Persada, 2008), h. 45.

6Muhammad Syafi'i Antonio, Bank Syari'ah dari Teori ke Praktek, h. 131.

7Atang Abd Hakim, Figh Perbankan Syariah (Bandung: PT. Refika Aditama, 2011), h. 267. 
4. Nasabah qardh dapat memberikan tambahan (sumbangan) dengan sukarela kepada LKS selama tidak diperjanjikan dalam akad.

5. Jika nasabah tidak dapat mengembalikan sebagian atau seluruh kewajibannya pada saat yang telah disepakati dan LKS telah memastikan ketidakmampuannya, LKS dapat:

a. Memperjuangkan jangka waktu pengambilan, atau

b. Menghapus sebagian atau seluruh kewajibannya.

\section{Kedua: Sanksi}

1. Dalam hal nasabah tidak menunjukkan keinginan mengembalikan sebagian atau seluruh kewajibannya dan bukan karena ketidakmampuannya, LKS dapat menjatuhkan sanksi kepada nasabah.

2. Sanksi yang dijatuhkan kepada nasabah sebagaimana yang dimaksud butir 1 dapat berupa dan tidak terbatas pada penjualan barang jaminan.

3. Jika barang jaminan tidak mencukupi, nasabah tetap harus memenuhi kewajibannya secara penuh.

\section{Ketiga : Sumber Dana Qardh Dapat Bersumber dari:}

1. Bagian modal LKS

2. Ketentuan LKS yang disisihkan

3. Lembaga lain atau individu yang mempercayakan penyaluran infaqnya kepada LKS

\section{Keempat:}

1. Jika salah satu pihak tidak menunaikan kewajibannya atau jika terjadi perselisihan di antara para pihak, maka penyelesaiannya dilakukan melalui Badan Arbitrasi Syari'ah setelah tidak tercapai kesepakatan melalui musyawarah.

2. Fatwa ini berlaku sejak tanggal ditetapkan dengan ketentuan jika dikemudian hari ternyata terdapat kekeliruan, maka akan diubah dan disempurnakan sebagaimana mestinya. ${ }^{8}$

\section{Syarat dan Rukun Qardh}

Agar akad yang dilakukan menjadi sah, maka dijelaskan syarat dan rukunnya, sebagai berikut:

a. Orang yang memberikan pinjaman atau menyediakan harta harus mempunyai kecakapan dalam menggunakan hartanya secara mutlak menurut pandangan syara' tanpa suatu paksaan, dan jika memberikan pinjaman harus berdasarkan kehendaknya sendiri, tanpa ada pihak ketiga yang ikut campur. ${ }^{9}$

b. Orang yang meminjam suatu benda atau harta harus seseorang yang sudah akil balig, sehat akalnya, serta bukan orang yang tidak diperkenankan oleh agama untuk mengatur hartanya sendiri. Jadi, apabila ada anak kecil yang belum baligh maupun orang yang tidak waras yang melakukan transaksi peminjaman maka

8Dewan Syariah Nasional MUI, Himpunan Fatwa Keuangan Syariah (Jakarta: Erlangga, 2014), h. 132.

9Ahmad Rahman Ghazaly, Fiqh Muamalat (Jakarta: Kencana Pernada Media Group, 2010), h. 52. 
hukumnya tidak sah dan dianggap tidak memenuhi syarat yang telah ditentukan oleh agama. ${ }^{10}$

c. Harta yang dipinjamkan harus mitsli (menurut mazhab Hanafiyah), namun jumhur ulama memperbolehkan harta apa saja yang bisa dijadikan tanggungan, seperti uang, biji-bijian dan harta mitsli seperti hewan, barang tidak bergerak dan sebagainya. Harta yang dipinjamkan jelas ukurannya, baik dalam takaran, timbangan, bilangan, serta ukuran panjang agar mudah dikembalikan. ${ }^{11}$

d. Shigat (ijab dan qabul), dapat dilakukan secara lisan, tulisan atau isyarat yang memberikan pengertian dengan jelas tentang adanya ijab dan qabul yang di dalamnya tujuan akad harus jelas dan dapat dipahami, antara ijab dan qabul harus ada kesesuaian dengan kehendak masing-masing dan tidak boleh ada yang meragukan. ${ }^{12}$ Ada aturan umum yang mesti ada dalam perjanjian qardh itu, yaitu timbangan, takaran, jumlah, bentuk, dan sifatnya harus terang; selanjutnya adalah orang yang memberi pinjaman memang layak meminjamkan. Layak yang dimaksud di sini adalah mampu memberi sesuatu yang akan dipinjamkan dalam keadaan waras keadaannya. ${ }^{13}$

\section{B. Prosedur Jual Beli Kredit}

Islam mengatur setiap apa yang ada dalam kehidupan, termasuk di dalamnya tentang muamalah seperti penelitian yang akan dikupas kali ini yaitu tentang hukum jual beli angsuran (kredit) dalam Syariah. Untuk memahami hukum jual beli angsuran terlebih dahulu kita fahami makna jual beli angsuran (kredit) tersebut.

Jual beli angsuran (kredit) ini masih diminati sampai saat ini, yaitu cara menjual barang dengan pembayaran secara tidak tunai (pembayaran ditangguhkan atau diangsur). ${ }^{14}$ Dalam ilmu fikih, akad jual beli kredit ini lebih dikenal dengan istilah jual beli taqsith. Secara bahasa, taqsith berarti membagi atau menjadikan sesuatu beberapa bagian, meskipun cara seperti ini adalah cara klasik, namun terbukti hingga kini masih menjadi trik yang sangat jitu untuk menjaring pasar, bahkan cara seperti ini terus-menerus dikembangkan dengan berbagai modifikasi.

Kredit adalah suatu pembelian yang dilakukan pada sesuatu barang, pembayaran harga barang tersebut dilakukan dengan cara berangsur-angsur sesuai tahapan pembayaran yang disepakati kedua belah pihak (pembeli dan penjual). Jenis jual beli kredit yang marak dipraktikkan dewasa ini adalah jual beli kredit kepemilikan rumah, yang masyhur disebut sebagai KPR, kemudian kredit

10Ahmad Rahman Ghazaly, Fiqh Muamalat (Jakarta: Kencana Pernada Media Group, 2010), h. 52.

11Ahmad Wardi Mulich, Fiqh Muamalat (Jakarta: AMZAH, 2010), h. 278.

12M. Ali Hasan, Berbagai Macam Transaksi Dalam Islam (Jakarta: PT. Raja Grafindo Persada, 2002), h. 104.

13Ismail Nawawi, Fiqh Mu'amalah (Surabaya: VIV Grafika, 2010), h. 110.

14KBBI. 
kendaraan (seperti motor atau mobil), juga kredit alat-alat rumah tangga, dan lain dan masih banyak lagi. ${ }^{15}$

Sebagai contoh adalah ketika seseorang ingin membeli motor misalnya, namun uangnya tidak cukup untuk membayar secara kontan, dengan alasan itu sipedagang menawarkan dengan harga kredit dan tempo pembayaran, misalnya jika dengan membeli kontan maka harga motor tersebut adalah $\mathrm{Rp} 30.000 .000$,sedangkan secara kredit, pedagang akan mengambil keuntungan, misalnya Rp 1.000.000,- jumlah harga naik menjadi Rp 31.000.000,- penambahan harga tersebut adalah secara angsuran, ketika sejak awal kesepakatan terjadi di antara keduanya, jual beli kredit seperti ini saling mengetahui, sukarela dan saling menguntungkan, baik bagi si-pembeli karena kredit meringankan pembayarannya dan bagi pedagang menguntungkan, jadi sama-sama mendapat keuntungan yang tidak memberatkan kedua belah pihak.

Penambahan harga hampir terjadi di dalam semua sistem jual beli dan ini berlaku umum. Penambahan harga dalam jual beli tidaklah dilarang, selama tambahan-tambahan tersebut tidak merugikan atau mengandung unsur zhalim. ${ }^{16}$

\section{B. Aturan Islam Mengenai Kredit}

Hakikat membeli barang secara kredit adalah membeli barang secara berhutang. Hutang tidak dianjurkan dalam syari' at Islam kecuali seseorang sangat membutuhkan barang tersebut dan ia merasa mampu untuk melunasinya. Maka tidak dianjurkan seorang muslim untuk membeli barang yang merupakan kebutuhan secara kredit. ${ }^{17}$

Secara umum, jual beli dengan cara kredit diperbolehkan oleh syariat. Berdasarkan pada beberapa dalil, di antaranya adalah bolehnya berhutang dengan cara kredit atau angsuran dengan cara menuliskan jumlah hutang, pembayaran di awal, berapa kali angsuran, dan pelunasan tanggal pembayaran, yang sekarang disebut sebagai kwitansi tanda bukti pembayaran hutang, dan cara ini diperintahkan dalam QS. Al Baqarah: 282 sebagai berikut:

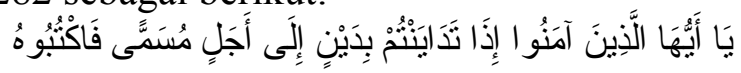

"Hai orang-orang yang beriman, apabila kamu bermuamalah tidak secara tunai untuk waktu yang ditentukan, hendaklah kamu menuliskannya." (QS. Al Baqarah : 282)

Ayat ini adalah sebagai dalil bolehnya akad hutang-piutang, sedangkan akad kredit merupakan salah satu bentuk hutang, sehingga keumuman ayat tersebut bisa menjadi dasar bolehnya akad kredit.

Dalam hadis riwayat 'Aisyah ra, dikatakan:

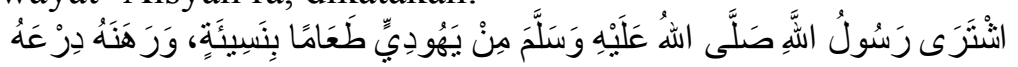

15 Al-Hakim Lukman dan Muslim Muslihun, Muqaranah fi al-Muamalah (Yogyakarta, Kurnia Alam Semesta, 2010), h. 42.

16Imam Mustofa, Fiqih Muamalat Kontemporer (Jakarta: Rajawali Pres, 2016), h. 60.

17Erwandi Tarmizi, Harta Haram Muamalat Kontemporer (Cet: 16, PT. Berkat Mulia Insani, Bogor, 2017), h. 418. 
"Rasulullah Saw membeli sebagian bahan makanan dari seorang yahudi dengan pembayaran dihutang dan beliau juga menggadaikan perisai kepadanya." (HR. Bukhari:2096 dan Muslim: 1603)

Dalam hadis ini Rasulullah Saw membeli bahan makanan dengan sistem pembayaran dihutang, itulah hakikat kredit dengan menggadaikan perisainya. Menggadai barang sebagai jaminan pembayaran yang memiliki jangka waktu yang terbatas atau dibatasi.

Berdasarkan dalil di atas, jual beli dengan sistem kredit hukumnya diperbolehkan dalam syariat. Membayar harga secara kredit diperbolehkan, asalkan tempo atau waktu ditentukan dan jumlah pembayaran telah ditentukan sesuai kesepakatan.

Jual beli dengan sistem angsuran (kredit), dalam istilah kaidah fiqhiyah bahwa asal dalam muamalah adalah mubah, kecuali ada dalil yang menunjukkan keharamannya. Dalam QS. Al-Baqarah: 275 Allah SWT berirman, sebagai berikut:

Terjemahnya:

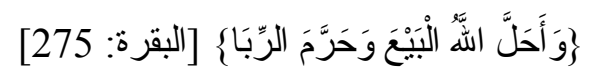

“... Allah telah menghalalkan jual beli dan mengharamkan riba ...”

Jual beli adalah halal, sedangkan riba haram. Jika dalam jual beli kredit mengandung riba, maka jual beli tersebut menjadi haram. Demikian yang dimaksud ayat tersebut. Jadi asal dalam muamalah termasuk di dalamnya jual beli kredit adalah boleh atau mubah.

\section{SIMPULAN DAN REKOMENDASI}

Setelah melakukan penelusuran dan penelitian hukum jual beli angsuran (kredit) dalam syariah Islam, maka penulis dapat mengambil kesimpulan sebagai berikut:

1. Jual beli dengan sistem angsuran (kredit) adalah pinjaman yang diberikan kepada seseorang yang memerlukan. aturannya, antara lain bahwa ketika waktu yang telah disepakati telah tiba maka wajib mengembalikan jumlah pokok pinjamannya; bila ada biaya administrasi maka itu menjadi tanggungan orang yang meminjam; ketika dipandang perlu orang yang memberi pinjaman dapat meminta jaminan; bila orang yang meminjam (kreditor) memberi tambahan sebagai sumbangan sukarela kepada pemberi kredit maka sumbangan itu boleh diterima dengan catatan bahwa itu tidak ada dalam perjanjian akadnya; Jika ditakdirkan kreditor tidak dapat membayar kreditnya sesuai dengan waktu yang telah disepakati maka pemberi pinjaman (setelah dia pastikan ketidakmampuan kreditor) boleh mengambil tindakan untuk memperpanjang jangka waktu pengambilan atau menghapus sebagian atau keseluruhan tanggungan kreditor sebagai sebuah kebajikan. 
2. Hukum jual beli angsuran (kredit) dalam syariah Islam itu boleh (jaiz/mubah) selama tidak ada kezaliman di dalamnya, tidak ada unsur riba, serta dilakukan atas dasar sukarela.

Penelitian ini perlu dikaji dan terus disosialisasikan agar umat bisa lebih memahami dan secara konsisten mengamalkan syariah secara utuh demi terjaminnya keberkahan muamalah itu sendiri.

\section{DAFTAR PUSTAKA}

Antonio, Muhammad Syafi'i. 2001. Bank Syari'ah Dari Teori Ke Praktik. Jakarta: Gema Insani.

Ascaya. 2008. Akad dan Produk Bank Syari'ah. Jakarta: PT. Raja Grafindo Persada.

Dewan Syariah Nasional MUI. 2014. Himpunan Fatwa Keuangan Syariah. Jakarta: Erlangga.

Ghazaly, Ahmad Rahman. 2010. Fiqh Muamalat. Jakarta: Kencana Pernada Media Group.

Hakim, Atang Abd. 2011. 2007. Fiqh Perbankan Syariah. Bandung: PT. Refika Aditama.

Hasan, M. Ali. 2002. Berbagai Macam Transaksi Dalam Islam. Jakarta: PT. Raja Grafindo Persada.

Lukman, Al-Hakim dan Muslim Muslihun. 2010. Muqaranah fi al-Muamalah. Yogyakarta, Kurnia Alam Semesta.

Moleong, Lexy J. 2010. Metodelogi Penelitian Kualitatif. Bandung: PT. Remaja Rosdakarya.

Mulich, Ahmad Wardi. 2010. Fiqh Muamalat. Jakarta: AMZAH.

Mustofa, Imam. 2016. Fiqih Muamalat Kontemporer. Jakarta: Rajawali Press.

Nawawi, Ismail. 2010. Fiqh Mu'amalah. Surabaya: VIV Grafika.

Sjahdeini, Sutan Remy. 1999. Perbankan Islam dan Kedudukannya dalam Tata Hukum Perbankan Indonesia. Jakarta: Pustaka Umum Grafiti.

Tarmizi, Erwandi. 2017. Harta Haram Muamalat Kontemporer. Cet: 16. PT. Berkat Mulia Insani, Bogor.

Yunus, Mahmud. t.th. Kamus Arab-Indonesia. Jakarta: Hidakarya Agung. 